\title{
Covariation of copy number located at 16q22.1: New evidence in mammary ductal carcinoma
}

\author{
QIAN SUN ${ }^{1}$, YAN-MEI YANG ${ }^{2}$, SHI-HUI YU ${ }^{3}$, YOU-XUE ZHANG ${ }^{1}$, XIAO-GUANG HE ${ }^{1}$, \\ SHAN-SHAN SUN ${ }^{1}$, XIAO-SHUAN LIANG ${ }^{1}$ and DA PANG ${ }^{1,2}$ \\ ${ }^{1}$ Department of Breast Surgery, The Third Affiliated Hospital of Harbin Medical University; ${ }^{2}$ Cancer Research Institute, \\ Harbin Medical University, Harbin 150081, P.R. China; ${ }^{3}$ Department of Pathology, \\ Children's Mercy Hospitals and Clinics, Kansas City, MO, USA
}

Received June 29, 2012; Accepted August 7, 2012

DOI: $10.3892 /$ or.2012.2050

\begin{abstract}
Copy number variation (CNV) is crucial for gene regulation in humans. A number of studies have revealed that $\mathrm{CNV}$ contributes to the initiation and progression of cancer. In this study, we analysed four breast cancer cell lines and six fresh frozen tissues from patients to evaluate the CNV present in the genome using microarray-based comparative genomic hybridization (aCGH). Six genes located at 16q22.1 were analysed by real-time PCR. The real-time PCR analysis revealed that the loss of CDH1/E2F4 may be associated with worse clinical and pathological findings. Interestingly, covariation of CDH1, CDH3, CTCF and E2F4 was found to be associated with triple negative breast cancer and HER-2 receptor status. In conclusion, our study supports the idea that CNV at 16q22.1 in breast cancer is a frequent event; furthermore, it reveals the covariation of CDH1, CDH3, CTCF and E2F4. The role of the covariation is more complex than a simple additive effect of these four separate genes, which may provide a novel target for breast cancer.
\end{abstract}

\section{Introduction}

Breast cancer is the most frequently diagnosed cancer and is the leading cause of cancer deaths in females worldwide, accounting for $23 \%$ (1.38 million) of the total new cancer cases and $14 \%$ $(458,400)$ of the total cancer deaths in 2008 (1). As one of the most heterogeneous human tumours (2), multiple pathways are known to lead to tumourigenesis, and each pathway involves multiple steps contributing to tumourigenic progression.

Correspondence to: Dr Da Pang, Department of Breast Surgery, The Third Affiliated Hospital of Harbin Medical University, Harbin 150081, P.R. China

E-mail: pangdasir@163.com

Dr Yan-Mei Yang, Cancer Research Institute, Harbin Medical University, Harbin 150081, P.R. China

E-mail: yangym0916@163.com

Key words: breast cancer, 16q22.1, copy number variation, covariation of copy number, real-time PCR
Chromosomal aberrations such as deletions, amplifications, or other forms of structural rearrangements have a major impact on tumour development (3).

Copy number variation (CNV), a significant source of genetic variation in humans, is one of substantial structural variations that affects the stability of the human genome $(4,5)$. Constitutional CNVs might be associated with disease, including cancer predisposition (6). For example, changes in the copy number of genes such as ERBB2 (7) and c-MYC have been extensively documented in breast cancer and are present in model cell lines. Amplified (and overexpressed) genes are prime therapeutic targets; for example, the use of the drug trastuzumab against ERBB2 has been shown to improve breast cancer survival rates either alone or in combination with other treatments. This finding suggests that newly identified changes in copy number may provide new markers for breast cancer diagnosis, monitoring progression, therapeutic selection, and prognostic prediction.

The goal of our study was to find associations between CNVs and different tumour characteristics to identify new biomarkers for mammary ductal carcinoma.

\section{Materials and methods}

Specimens. Human breast tissues were collected from female breast cancer patients who were diagnosed and treated at the Third Affiliated Hospital of Harbin Medical University in 2010 (Table I). Primary tumour tissue and paired non-tumour tissues were initially frozen in liquid nitrogen within half an hour after surgery and then stored at $-80^{\circ} \mathrm{C}$ for long-term storage. All samples were inspected by pathologists to confirm that they consisted of $>80 \%$ cancer cells. All non-tumour tissues were obtained from the same patient's breast tissue $\leq 5 \mathrm{~cm}$ away from the edge of tumour during mastectomy. Cell lines HCC70, HCC202, HCC1937 and HCC2218 were purchased from ATCC (Rockville, MD). The study was approved by the Research Ethics Committee of the hospital.

Experimental procedures

DNA preparation. Axygen ${ }^{\circledR}$ AxyPrep Multisource Genomic DNA Minprep kit (Axygen, Union City, CA, USA) and Pure Gene kit (Gentra Systems, Minneapolis, MN, USA) were used to extract genomic DNA as described by the manufacturer. 
Table I. Clinical and pathological composition of tumour patients.

\begin{tabular}{ccc}
\hline & $\mathrm{n}$ & $\operatorname{Per}(\%)$ \\
\hline Total & 101 & 100
\end{tabular}

Tumour size

$\begin{array}{rrr}\text { pT1 } & 42 & 41.6 \\ \text { pT2 } & 52 & 51.5 \\ \text { pT3 } & 7 & 6.9\end{array}$

Node metastasis

0

$1-4$

$>5$

23.8

TNM classification

$$
0
$$

I

II

III

ER - 38

$+-+++\quad 63$

37.6

62.4

PR

$\begin{array}{ll}- & 48\end{array}$

$+-+++53$

47.5

Her-2

- 46

$+-+++\quad 55$

45.5

54.5

P53

$\begin{array}{ll}- & 74\end{array}$

$+-+++27$

73.3

Ki67

$-\quad 28$

$+-+++\quad 73$

27.7

72.3

Family history

Yes

89

No tumour DNA was labelled with Fluoro Link Cy3-conjugated $\mathrm{dUTP}$ as the control. Then, $1.5 \mu \mathrm{g}$ of gDNA was labelled and hybridised to the array at $65^{\circ} \mathrm{C}$ for $40 \mathrm{~h}$. For the cell lines, Agilent's 44k Human genome Gene Chip (Agilent Technologies, Palo Alto, CA, USA) was used to scan the whole genome. For the aCGH analysis, 100 ng of DNA was digested by Alu 1 and Rsa 1 (Invitrogen, Carlsbad, CA, USA) and labelled in the same manner. The hybridisation reaction was performed on an Agilent 2565AA DNA microarray scanner. Microarray images were analysed using Feature Extraction software. Finally, CGH Analytics software was used to analyse the data by the z-scoring method, with the parameters of a window of $1 \mathrm{M}$ and threshold of 4 .

Real-time PCR. The copy number of candidate genes, CDH1, $\mathrm{CDH} 3, \mathrm{CDH} 5, \mathrm{E} 2 \mathrm{~F} 4, \mathrm{CTCF}$ and TRF2, were quantified using the real-time PCR method. Briefly, total genomic DNA was extracted from 101 mammary ductal carcinoma tumour samples and their non-tumour tissue samples. Experiments were performed on the ABI PRISM 7000 Sequence Detection System (Applied Biosystems, Foster City, CA, USA) using Fast-Start Universal SYBR Green Master (ROX) (2x) (Roche, Germany) according to the manufacturer's istructions. Primers for the candidate genes were designed based on the sequence data obtained from the NCBI database (http://www.ncbi.nlm. nih/org) using Primer 5.0 software (Table II). Comparative $\mathrm{Ct}$ (threshold cycle) method was employed to quantify gene copy number. Candidate gene copy number $=2^{-\Delta \Delta \mathrm{Ct}}=2^{-[(\mathrm{Ct} \text { candidate gene }}$ _ Ct $\beta$-actin)cancer group _ (Ct candidate gene _ Ct $\beta$-actin)control group]. All samples were tested at least twice, and the median $\mathrm{Ct}$ values were established; $2^{-\Delta \Delta \mathrm{Ct}}>2.0$ was classified as an amplification and $2^{-\Delta \Delta \mathrm{Ct}}<0.5$ as a deletion (8).

Statistical analysis. The $\chi^{2}$ test and rank-sum test were used to evaluate associations of the clinical and pathological parameters with gene CNV. For each gene, patients were divided into amplified/non-amplified groups (amplification vs. normal + deletion) and loss/non-loss groups (deletion vs. normal + amplification). All statistical calculations were performed using SPSS version 17.0 for Windows. Associations were calculated with Spearman's rho. Two-tailed P-values of $<0.05$ were considered statistically significant. Unsupervised hierarchical cluster analysis (Euclidean distance, average linkage analysis) was performed using cluster 3.0 software. The k-means algorithm was used to classify the covariation into an amplification group, normal group and deletion group.

\section{Results and Discussion}

Complex copy number variations were found at 16q22.1 by $a C G H$. CNVs exist in both cancers and normal human genomes $(4,5)$. Genome-wide screening for CNVs in breast cancer will facilitate the identification of tumour suppressor genes (TSG) and oncogenes. In this study, we identified 200 CNV segments including gains and losses. The size of CNV amplifications ranged from $20 \mathrm{~kb}$ to $245 \mathrm{Mb}$ with an average gain of $40 \mathrm{Mb}$ across an average of 80 separate CNVs events. The size of $\mathrm{CNV}$ deletions ranged from $35 \mathrm{~kb}$ to $138 \mathrm{Mb}$ with an average loss of $25 \mathrm{Mb}$ across an average of 91 separate CNVs events.

Interesting variations were detected at 16q22.1: two of the six
(Agilent, Santa Clara, CA, USA). Briefly, tumour tissue DNA was labelled with Fluoro Link Cy5-conjugated dUTP and non- $a C G H$. DNA from six fresh frozen tissue samples and four cell lines were investigated by microarray-based comparative genomic hybridization (aCGH) using the Agilent $244 \mathrm{~K}$ oligonucleotide array according to the manufacturer's instructions 
Table II. Sequences of the primers for the six candidate genes at 16q22.1.

\begin{tabular}{|c|c|c|c|}
\hline Genes & Primers & Primer sequences $5^{\prime} \rightarrow 3^{\prime}$ & Accession no. \\
\hline \multirow[t]{2}{*}{$\beta$-actin } & $\mathrm{F}$ & GTCACCAACTGGGACA & NT_007819.17 \\
\hline & $\mathrm{R}$ & CGCTTTACACCAGCCTCAT & \\
\hline \multirow[t]{2}{*}{ CDH1 } & $\mathrm{F}$ & CGTCACCGCTTCCCTTCTT & NT_010498.15 \\
\hline & $\mathrm{R}$ & CCACCTCCTCCGACCTCACTT & \\
\hline \multirow[t]{2}{*}{$\mathrm{CDH} 3$} & $\mathrm{~F}$ & TTCCTCACTCGCTCCTCC & NT_010498.15 \\
\hline & $\mathrm{R}$ & CCGTTTGGCTTTCTTTCC & \\
\hline \multirow[t]{2}{*}{ CDH5 } & $\mathrm{F}$ & ATCCACCCGCCACAGTTT & NT_010498.15 \\
\hline & $\mathrm{R}$ & TCGGTGCTTGGTCTTCATCC & \\
\hline \multirow[t]{2}{*}{ CTCF } & $\mathrm{F}$ & ACGCTTTCTATGTCTCCTT & NT_010498.15 \\
\hline & $\mathrm{R}$ & AАCTATCAATCAACGCTACTG & \\
\hline \multirow[t]{2}{*}{ E2F4 } & $\mathrm{F}$ & GGAGCACCGCCTCACTAA & NT_010498.15 \\
\hline & $\mathrm{R}$ & ACACGCCAGGGAAGAGTT & \\
\hline \multirow[t]{2}{*}{ TRF2 } & $\mathrm{F}$ & GCTCTTCCСАСТTТАССС & NT_010498.15 \\
\hline & $\mathrm{R}$ & GAATAGCCTTCACATCTTT & \\
\hline
\end{tabular}

F, forward; R, reverse.

A

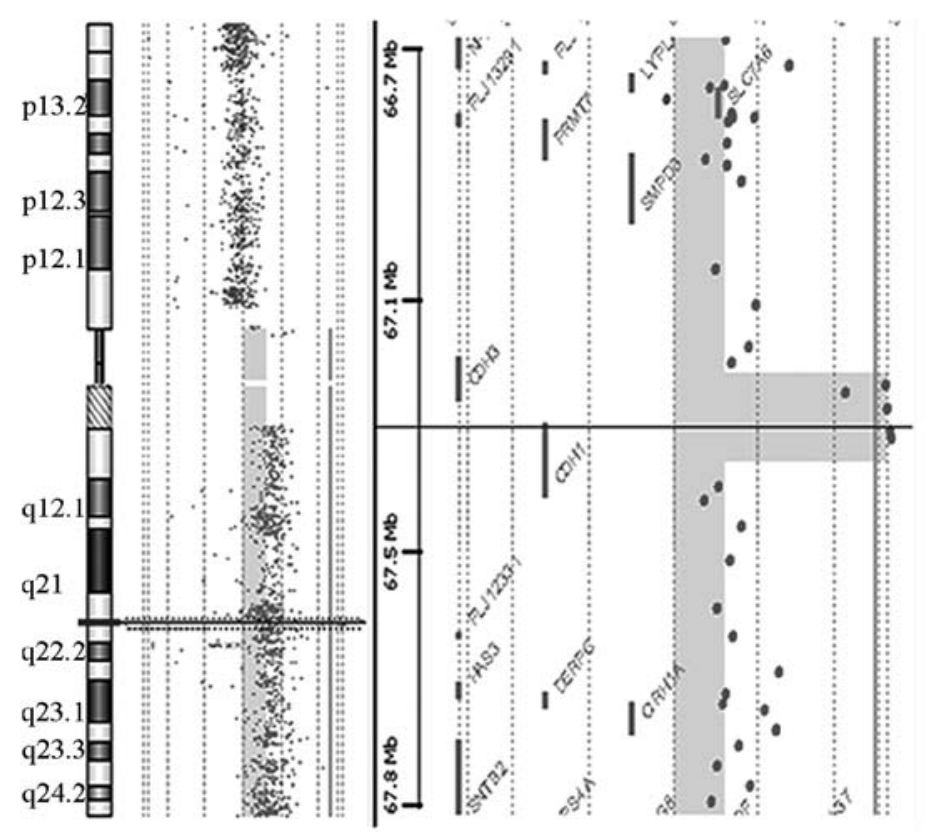

B

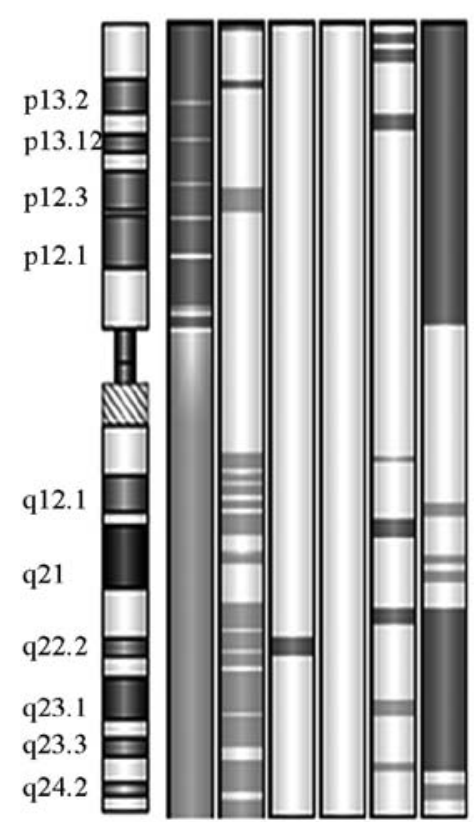

Figure 1. (A) A 30-fold copy number amplification was detected at 16q22.1 in breast cancer cell line HCC2218 by aCGH; (B) Deletion at 16q22.1 was detected in two of the six breast tumour tissues by aCGH. *Dark gray represents amplification and light gray represents deletion.

tissues had a deletion at this locus while one cell line had an amplification (Fig. 1). Although it has been reported that chromosome 16 is one of the most frequently altered chromosomes in breast cancer with a loss of heterozygosity at 16q occurring in about half of the low-grade ductal carcinomas and slightly more frequently in lobular carcinomas (9-13), the amplification of a DNA segment at 16q22.1 by $>30$-fold is described for the first time in the cell line HCC2218 by our study (Fig. 1). Thus, further research is needed to determine the significance of this distinct variation in a breast cancer.

Quantitation of candidate gene CNVs in 101 mammary ductal carcinoma patients by real-time PCR. Some candidate tumour suppressor genes are located in this region, such as $\mathrm{CDH} 1$ 


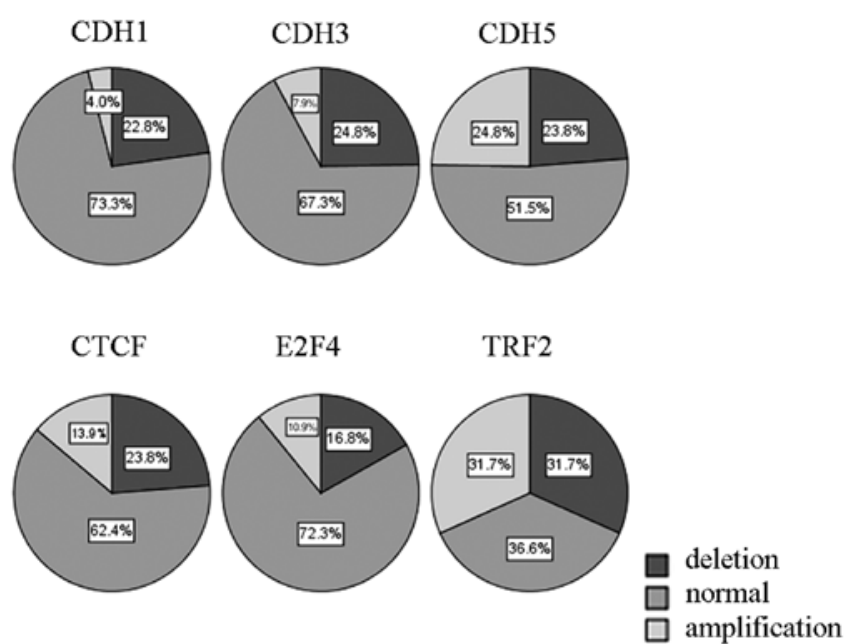

Figure 2. A pie chart of gray scale describing CNVs of CDH1, CDH3, CDH5, CTCF, E2F4, TRF2 in 101 breast cancer patients detected by real-time PCR method.
(14-18), CDH3 (19,20), CDH5 (21), E2F-4 (22), CTCF (23) and TRF2 (24,25). We selected these six genes for copy number quantitation in patients.

Sequence loss was commonly observed for all of the six candidate genes (Fig. 2). Among the 101 specimens, $22.8 \%$ showed a loss of $\mathrm{CDH} 1$ while the percentage showing amplification was only $4.0 \%$. A similar finding was noted among $\mathrm{CDH} 3, \mathrm{CTCF}$ and E2F4 with losses in 24.8, 23.8 and $16.8 \%$ of the specimens, respectively, and with a lower corresponding percentage showing amplifications.

For CDH5 and TRF2, a total of 24.8 and $31.7 \%$ of the specimens had amplifications of CDH5 and TRF2, respectively, which is higher than that observed in the other four genes. Among these, $10.9 \%$ specimens showed a high number of TRF2 amplifications $\left(2^{-\Delta \Delta \mathrm{Ct}}>10\right)$.

Unlike the findings in the HCC2218 cell line, patients tended to present with a loss at $16 \mathrm{q} 22.1$ in general. HCC2218 is a poorly differentiated cell line that is derived from the primary tumour of an invasive ductal carcinoma in an individual with a posi-

Table III. Association of CNVs with clinical and pathological features.

\begin{tabular}{|c|c|c|c|c|c|c|c|c|c|c|}
\hline & $\begin{array}{c}\text { TNM } \\
0 / 1 / 2 / 3\end{array}$ & $\begin{array}{l}\text { Node } \\
0 / 1 / 2\end{array}$ & $\begin{array}{l}\text { ER } \\
-/+\end{array}$ & $\begin{array}{l}\text { PR } \\
-/+\end{array}$ & $\begin{array}{c}\text { HER-2 } \\
-/+\end{array}$ & $\begin{array}{c}\mathrm{Ki} 67 \\
-/+\end{array}$ & $\begin{array}{c}\text { P53 } \\
-/+\end{array}$ & $\begin{array}{c}\text { Triple } \\
\text { negative } \\
\text { Yes/no }\end{array}$ & $\begin{array}{l}\text { Family } \\
\text { history } \\
\text { Yes/no }\end{array}$ & $\begin{array}{c}\text { Pathological } \\
\text { classification } \\
0 / 1 / 2 / 3\end{array}$ \\
\hline $\begin{array}{l}\text { CDH1 } \\
\text { loss/non-loss }\end{array}$ & $\mathrm{P}=0.009$ & $\mathrm{P}=0.022$ & $\mathrm{P}=0.717$ & $\mathrm{P}=0.621$ & $\mathrm{P}=0.958$ & $\mathrm{P}=0.055$ & $\mathrm{P}=0.538$ & $\mathrm{P}=0.204$ & $\mathrm{P}=0.845$ & $\mathrm{P}=0.747$ \\
\hline $\begin{array}{l}\text { CDH3 } \\
\text { loss/non-loss }\end{array}$ & $\mathrm{P}=0.509$ & $\mathrm{P}=0.444$ & $\mathrm{P}=0.234$ & $\mathrm{P}=0.355$ & $\mathrm{P}=0.560$ & $\mathrm{P}=0.972$ & $\mathrm{P}=0.722$ & $\mathrm{P}=0.034$ & $\mathrm{P}=0.148$ & $\mathrm{P}=0.509$ \\
\hline $\begin{array}{l}\text { CDH5 } \\
\text { loss/non-loss }\end{array}$ & $\mathrm{P}=0.431$ & $\mathrm{P}=0.304$ & $\mathrm{P}=0.132$ & $\mathrm{P}=0.034$ & $\mathrm{P}=0.273$ & $\mathrm{P}=0.081$ & $\mathrm{P}=0.455$ & $\mathrm{P}=0.181$ & $\mathrm{P}=0.407$ & $\mathrm{P}=0.100$ \\
\hline $\begin{array}{l}\text { CDH5 } \\
\text { amp/non-amp }\end{array}$ & $\mathrm{P}=0.033$ & $\mathrm{P}=0.304$ & $\mathrm{P}=0.234$ & $P=0.166$ & $\mathrm{P}=0.414$ & $\mathrm{P}=0.632$ & $\mathrm{P}=0.722$ & $\mathrm{P}=0.031$ & $\mathrm{P}=0.489$ & $\mathrm{P}=0.062$ \\
\hline $\begin{array}{l}\text { CTCF } \\
\text { loss/non-loss }\end{array}$ & $\mathrm{P}=0.008$ & $\mathrm{P}=0.038$ & $\mathrm{P}=0.589$ & $\mathrm{P}=0.238$ & $\mathrm{P}=0.88$ & $\mathrm{P}=0.482$ & $\mathrm{P}=0.071$ & $\mathrm{P}=0.039$ & $\mathrm{P}=0.121$ & $\mathrm{P}=0.177$ \\
\hline $\begin{array}{l}\text { CTCF } \\
\text { amp/non-amp }\end{array}$ & $\mathrm{P}=0.269$ & $\mathrm{P}=0.901$ & $\mathrm{P}=0.201$ & $\mathrm{P}=0.100$ & $\mathrm{P}=0.805$ & $\mathrm{P}=0.939$ & $\mathrm{P}=0.413$ & $\mathrm{P}=0.234$ & $\mathrm{P}=0.234$ & $\mathrm{P}=0.059$ \\
\hline E2F4 & & & & & & & & & & \\
\hline loss/non-loss & $\mathrm{P}=0.039$ & $\mathrm{P}=0.758$ & $\mathrm{P}=0.767$ & $\mathrm{P}=0.536$ & $\mathrm{P}=0.711$ & $\mathrm{P}=0.865$ & $\mathrm{P}=0.784$ & $\mathrm{P}=0.402$ & $\mathrm{P}=0.987$ & $\mathrm{P}=0.641$ \\
\hline $\begin{array}{l}\text { TRF2 } \\
\text { loss/non-loss }\end{array}$ & $\mathrm{P}=0.072$ & $\mathrm{P}=0.162$ & $\mathrm{P}=0.066$ & $\mathrm{P}=0.021$ & $\mathrm{P}=0.232$ & $\mathrm{P}=0.014$ & $\mathrm{P}=0.217$ & $\mathrm{P}=0.234$ & $\mathrm{P}=0.035$ & $\mathrm{P}=0.024$ \\
\hline
\end{tabular}

For significant associations, the corresponding P-values following $\chi^{2}$ test are depicted in the table. For genes, loss/non-loss refers to deletion vs. normal + amplification while amp/non-amp refers to amplification vs. normal + deletion. For clinical and pathological features, $0 / 1 / 2 / 3$ staging of TNM are followed for standard of TNM-UICC classification; nodal 0/1/2 refers to no lymph node metastasis, 1-3 lymph nodes metastasis and $>4$ lymph nodes metastasis, respectively; pathological classification 0, 1,2 and 3 refers to ductal carcinoma in situ, infiltrating duct carcinoma I, II and III respectively; -/+ refers to negative and positive (ranging from + to +++), respectively. 
Table IV. Relationship of candidate genes CNVs in 101 breast cancers.

\begin{tabular}{|c|c|c|c|c|c|c|}
\hline & CDH1 & $\mathrm{CDH} 3$ & CDH5 & CTCF & $\mathrm{E} 2 \mathrm{~F} 4$ & TRF2 \\
\hline \multicolumn{7}{|l|}{ CDH1 } \\
\hline Coefficient correlation & & 0.645 & 0.567 & 0.477 & 0.618 & 0.592 \\
\hline Significance (2-tailed) & & $<0.001$ & $<0.001$ & $<0.001$ & $<0.001$ & $<0.001$ \\
\hline \multicolumn{7}{|l|}{$\mathrm{CDH} 3$} \\
\hline Coefficient correlation & & & 0.585 & 0.525 & 0.604 & 0.477 \\
\hline Significance (2-tailed) & & & $<0.001$ & $<0.001$ & $<0.001$ & $<0.001$ \\
\hline \multicolumn{7}{|l|}{ CDH5 } \\
\hline Coefficient correlation & & & & 0.445 & 0.499 & 0.569 \\
\hline Significance (2-tailed) & & & & $<0.001$ & $<0.001$ & $<0.001$ \\
\hline \multicolumn{7}{|l|}{ CTCF } \\
\hline Coefficient correlation & & & & & 0.496 & 0.505 \\
\hline Significance (2-tailed) & & & & & $<0.001$ & $<0.001$ \\
\hline \multicolumn{7}{|l|}{ E2F4 } \\
\hline Coefficient correlation & & & & & & 0.482 \\
\hline Significance (2-tailed) & & & & & & $<0.001$ \\
\hline \multicolumn{7}{|l|}{ TRF2 } \\
\hline \multicolumn{7}{|l|}{ Coefficient correlation } \\
\hline Significance (2-tailed) & & & & & & \\
\hline
\end{tabular}

tive family history of cancer and with lymph nodes metastases, which were highly positive for the expression of HER2, positive for the expression of $\mathrm{p} 53$, positive for the epithelial cell-specific marker epithelial glycoprotein-2 (EGP2) and for cytokeratin-19, but negative for the expression of the estrogen receptor (ER). However, cell lines do not always represent the genotypes of parental tumour tissues. Established cell lines carry cell linesspecific $\mathrm{CNVs}$ together with the aberrations detected in primary tumour tissues (26), and this might provide an explanation as to why no significant amplifications were detected in our cohort.

Association of single gene CNVs with clinical and pathological features. Associations between CNVs of these six genes with common clinical and pathological factors (age, histological type and grade, HER2, ER, PR, P53, Ki67, family history, tumour size) were analysed to obtain a more complete understanding of CNVs. A subset of the statistical results is shown in Table III.

Cadherins are calcium-dependent adhesion molecules that have been implicated in numerous cellular functions, ranging from controlling morphogenesis to suppressing tumour invasion and metastasis (27-29). CDH1 encodes E-cadherin, which is a calcium-dependent trans-membrane glycoprotein. It is involved in pathological cellular systems, such as the epithelialmesenchymal transition, which is a process frequently related to tumour de-differentiation and infiltration metastasis. In our study, a significant association could be noted between the loss of CDH1 and worse clinical findings, such as a later TNM classification $(\mathrm{P}=0.009)$ and a greater frequency of lymph node metastases $(\mathrm{P}=0.022)$, supporting $\mathrm{CDH} 1$ as a TSG in breast ductal cancer. $\mathrm{CDH} 3$ encodes $\mathrm{P}$-cadherin, P-cadherin expression shows a strong association with high histologic tumour grade scores, increased proliferation, Her-2 and p53 expression, a lack of the estrogen receptor and poor patient survival (19). In this study, no significant association was observed between CNVs of $\mathrm{CDH} 3$ and these aspects. VE-cadherin, encoded by $\mathrm{CDH} 5$, is up-regulated in invasive breast cancers, contributing to neovascularisation in tumours (30). However, the endothelial-specific VE-cadherin is low or absent in angiosarcomas, supporting a suppressive role for this protein in tumour progression (31). Amplification of $\mathrm{CDH} 5$ could be found in more triple negative breast cancers [ER(-), PR(-), HER-2(-)] than in non-triple negative breast cancer patients in this study $(\mathrm{P}=0.031)$, suggesting that more research is needed to further elucidate the role of CDH5 in breast cancer.

CTCF and E2F4 are two important transcription factors at this locus. CTCF is widely expressed in different aspects of gene regulation including promoter activation (32) and repression (33), hormone-responsive gene silencing (34), methylation-dependent chromatin insulation and genomic imprinting $(35,36)$. In addition, CTCF can inhibit cell growth and induce cell cycle arrest at multiple stages (37). In our study, the loss of CTCF may result in a worse TNM classification $(\mathrm{P}=0.008)$ and an increase in lymph node metastases $(\mathrm{P}=0.038)$, but fewer triple negative breast cancer patients were found with a loss of CTCF, compared with non-triple negative patients $(\mathrm{P}=0.039)$. E2F4, another transcription factor, has been thought to be a tumour suppressor in breast cancer (22). The key roles of 
A

B

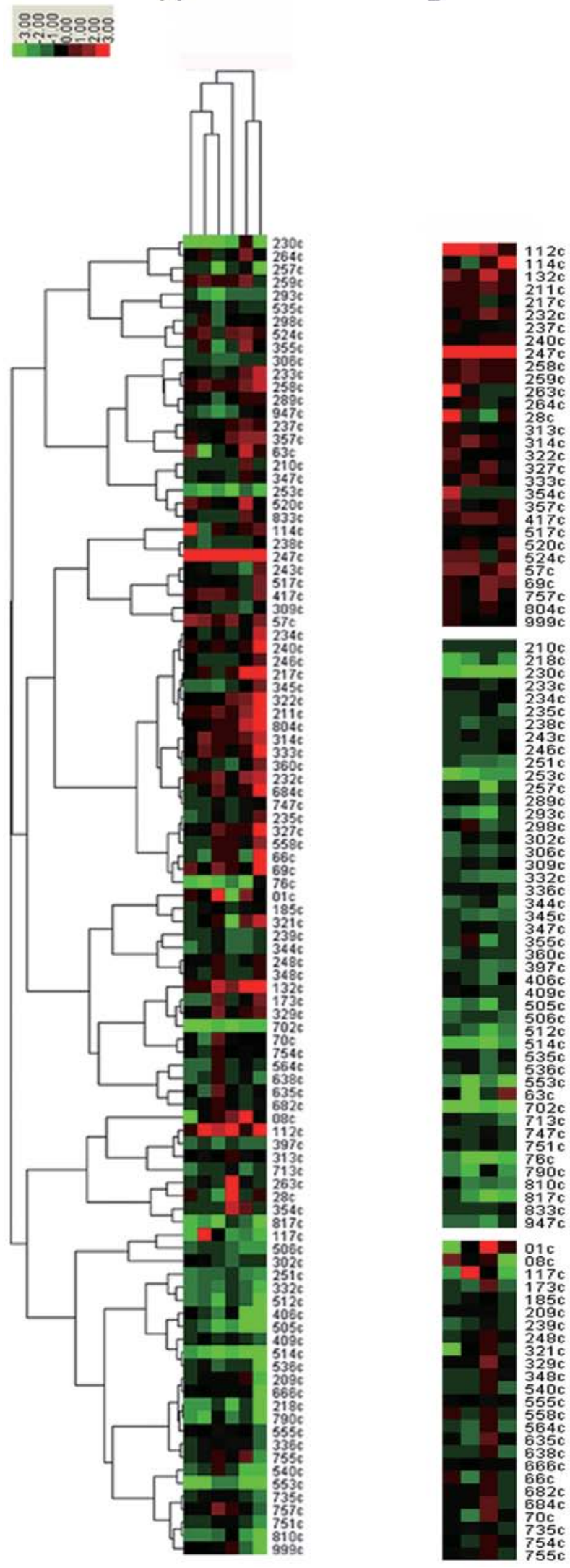

Figure 3. (A) Hierarchical cluster analysis of 101 breast cancer patients (vertical axis) analyzed by real-time PCR for 6 candidate genes (horizontal axis). DNA copy number gains and losses indicate as the color-bar; (B) Clustering of 101 mammary ductal carcinoma patients (vertical axis) by the k-means algorithm. The 4 genes (horizontal axis) used for the cluster analysis (left to right, E2F4 CDH3 CTCF CDH1). Depending on the situation of covariance, the samples were divided into 3 groups, the top group represents amplification, the bottom group represents loss.

E2F4 in preventing carcinogenesis are controlling the cell cycle, cell growth and apoptosis; moreover, E2F4 is associated with p130, p107 and pRb and is abundant in non-cycling cells (38). In our study, the loss of E2F4 was associated with a worse TNM classification ( $\mathrm{P}=0.039)$, supporting $\mathrm{E} 2 \mathrm{~F} 4$ as a TSG in breast cancer.

The TRF2 gene encodes a ubiquitous protein that is related to telomerase activity. It maintains telomere structure and function (39). Additionally, the inhibition of TRF2 has been found to induce apoptosis (40) and has been implicated in some cancers, such as gastric cancer and leukaemia $(24,41)$. We found that, in a considerable proportion of the patients, the amplification of TRF2 could be detected and that the loss of TRF2 might be related to a lower Ki67 positive ratio $(\mathrm{P}=0.012)$ and a higher $\mathrm{PR}$ positive ratio $(\mathrm{P}=0.012)$.

Covariation of $\mathrm{CDH1}, \mathrm{CDH} 3, \mathrm{CTCF}$ and E2F4 was found as well as associations between the variation and clinical and pathological features. In cancers, chromosomal variation of not only one single specific gene but also of several linked genes often contributes to pathogenesis $(42,43)$. Associations between CNVs of each gene were noted in our study (Table IV). Through hierarchical cluster analysis, an apparent cluster of CDH1, $\mathrm{CDH} 3, \mathrm{CTCF}$ and E2F4 was revealed, while CDH5 and TRF2 formed the other cluster (Fig. 3). This finding suggested that the genes $\mathrm{CDH} 1, \mathrm{CDH} 3, \mathrm{CTCF}$ and E2F4 are closely related to one another, so all specimens were divided into three groups (amplification/normal/deletion) using a covariation model of these four genes by the k-means algorithm. A total of 46 of the 101 patients $(45.5 \%)$ showed deletions in this region while 30 of the 101 patients (29.7\%) showed amplifications (Fig. 3). In this study, a covariation of CDH1, CDH3, CTCF and E2F4 was found for the first time. It is interesting that the other two genes, CDH5 and TRF2, map to the two ends of the locus while the other four genes are located in the middle (http://www.ncbi. nlm.nih/org). Using a $\chi^{2}$ test on the clinical and pathological features, we surprisingly found that triple negative breast cancers more frequently belonged to the non-deletion group (normal group/amplification group) rather than the deletion group $(\mathrm{P}=0.032)$. These results suggest that the role of covariation is more complex than a simple additive effect and may provide novel insight for us to evaluate the disease.

In conclusion, our study supports that sequence loss at 16q22.1 occurs commonly in mammary ductal carcinoma and covariation of copy number, including CDH1, CDH3, CTCF and $\mathrm{E} 2 \mathrm{~F} 4$, were found for the first time. The role of covariation is more complex than a simple additive effect, which may provide novel insight into the evaluation of the clinical and pathological attributes of this disease. $\mathrm{CDH} 1$ and $\mathrm{E} 2 \mathrm{~F} 4$ are supported as important TSGs of mammary ductal carcinoma. $\mathrm{CNV}$ of $\mathrm{CDH} 3, \mathrm{CDH} 5 \mathrm{CTCF}$ and TRF2 was also found to play a role in breast cancer, but more evidence is needed to clarify the effects of these genes.

\section{Acknowledgements}

This study was financially supported by Fund of Heilongjiang Provincial Finance Department (2008-02). The authors thank Dr Yashuang Zhao and Dr Wang Zhang for their assistance with the statistical analyses. 


\section{References}

1. Jemal A, Bray F, Center MM, Ferlay J, Ward E and Forman D: Global cancer statistics. CA Cancer J Clin 61: 69-90, 2011.

2. Rajski M, Vogel B, Baty F, Rochlitz C and Buess M: Global gene expression analysis of the interaction between cancer cells and osteoblasts to predict bone metastasis in breast cancer. PLoS One 7: e29743, 2012.

3. Nemes S, Parris TZ, Danielsson A, et al: Segmented regression, a versatile tool to analyze mRNA levels in relation to DNA copy number aberrations. Genes Chromosomes Cancer 51: 77-82, 2012.

4. Iafrate AJ, Feuk L, Rivera MN, et al: Detection of large-scale variation in the human genome. Nat Genet 36: 949-951, 2004.

5. Sebat J, Lakshmi B, Troge J, et al: Large-scale copy number polymorphism in the human genome. Science 305: 525-528, 2004.

6. Kuiper RP, Ligtenberg MJ, Hoogerbrugge N and Geurts van Kessel A: Germline copy number variation and cancer risk. Curr Opin Genet Dev 20: 282-289, 2010.

7. Staaf J, Jonsson G, Ringner M, Baldetorp B and Borg A: Landscape of somatic allelic imbalances and copy number alterations in HER2-amplified breast cancer. Breast Cancer Res 13: R129, 2011.

8. Bunyan DJ, Eccles DM, Sillibourne J, et al: Dosage analysis of cancer predisposition genes by multiplex ligation-dependent probe amplification. Br J Cancer 91: 1155-1159, 2004.

9. Hungermann D, Schmidt H, Natrajan R, et al: Influence of whole arm loss of chromosome 16q on gene expression patterns in estrogen receptor-positive, invasive breast cancer. J Pathol 224: 517-528, 2011.

10. Kai K, Zhang Z, Yamashita H, Yamamoto Y, Miura Y and Iwase H: Loss of heterozygosity at the ATBF1-A locus located in the $16 \mathrm{q} 22$ minimal region in breast cancer. BMC Cancer 8: 262, 2008.

11. Cleton-Jansen AM: E-cadherin and loss of heterozygosity at chromosome 16 in breast carcinogenesis: different genetic pathways in ductal and lobular breast cancer? Breast Cancer Res 4: 5-8, 2002

12. Cleton-Jansen AM, Callen DF, Seshadri R, et al: Loss of heterozygosity mapping at chromosome arm 16q in 712 breast tumors reveals factors that influence delineation of candidate regions. Cancer Res 61: 1171-1177, 2001.

13. Dorion-Bonnet F, Mautalen S, Hostein I and Longy M: Allelic imbalance study of $16 \mathrm{q}$ in human primary breast carcinomas using microsatellite markers. Genes Chromosomes Cancer 14 171-181, 1995.

14. Zou D, Yoon HS, Perez D, Weeks RJ, Guilford P and Humar B: Epigenetic silencing in non-neoplastic epithelia identifies E-cadherin (CDH1) as a target for chemoprevention of lobular neoplasia. J Pathol 218: 265-272, 2009.

15. Caldeira JR, Prando EC, Quevedo FC, Neto FA, Rainho CA and Rogatto SR: CDH1 promoter hypermethylation and E-cadherin protein expression in infiltrating breast cancer. BMC Cancer 6 : 48, 2006.

16. Berx G, Cleton-Jansen AM, Strumane K, et al: E-cadherin is inactivated in a majority of invasive human lobular breast cancers by truncation mutations throughout its extracellular domain. Oncogene 13: 1919-1925, 1996.

17. Berx G,Cleton-Jansen AM, Nollet F, et al: E-cadherin is a tumour/ invasion suppressor gene mutated in human lobular breast cancers. EMBO J 14: 6107-6115, 1995

18. Kanai Y, Oda T, Tsuda H, Ochiai A and Hirohashi S: Point mutation of the E-cadherin gene in invasive lobular carcinoma of the breast. Jpn J Cancer Res 85: 1035-1039, 1994.

19. Paredes J, Albergaria A, Oliveira JT, Jeronimo C, Milanezi F and Schmitt FC: P-cadherin overexpression is an indicator of clinical outcome in invasive breast carcinomas and is associated with CDH3 promoter hypomethylation. Clin Cancer Res 11: 5869-5877, 2005.

20. Gamallo C, Moreno-Bueno G, Sarrio D, Calero F, Hardisson D and Palacios J: The prognostic significance of P-cadherin in infiltrating ductal breast carcinoma. Mod Pathol 14: 650-654, 2001.

21. Kremmidiotis G, Baker E, Crawford J, Eyre HJ, Nahmias J and Callen DF: Localization of human cadherin genes to chromosome regions exhibiting cancer-related loss of heterozygosity. Genomics 49: 467-471, 1998 .

22. Ho GH, Calvano JE, Bisogna M and Van Zee KJ: Expression of E2F-1 and E2F-4 is reduced in primary and metastatic breast carcinomas. Breast Cancer Res Treat 69: 115-122, 2001.
23. Filippova GN, Lindblom A, Meincke LJ, et al: A widely expressed transcription factor with multiple DNA sequence specificity, CTCF, is localized at chromosome segment 16q22.1 within one of the smallest regions of overlap for common deletions in breast and prostate cancers. Genes Chromosomes Cancer 22: 26-36, 1998.

24. Matsutani N, Yokozaki H, Tahara E, et al: Expression of telomeric repeat binding factor 1 and 2 and TRF1-interacting nuclear protein 2 in human gastric carcinomas. Int J Oncol 19: 507-512, 2001.

25. Broccoli D, Chong L, Oelmann S, et al: Comparison of the human and mouse genes encoding the telomeric protein, TRF1: chromosomal localization, expression and conserved protein domains. Hum Mol Genet 6: 69-76, 1997.

26. Tsuji K, Kawauchi S, Saito S, et al: Breast cancer cell lines carry cell line-specific genomic alterations that are distinct from aberrations in breast cancer tissues: comparison of the CGH profiles between cancer cell lines and primary cancer tissues. BMC Cancer 10: 15, 2010.

27. Hazan RB, Qiao R, Keren R, Badano I and Suyama K: Cadherin switch in tumor progression. Ann NY Acad Sci 1014: 155-163, 2004.

28. Cavallaro U and Christofori G: Cell adhesion and signalling by cadherins and Ig-CAMs in cancer. Nat Rev Cancer 4: 118-132, 2004.

29. Birchmeier W and Behrens J: Cadherin expression in carcinomas: role in the formation of cell junctions and the prevention of invasiveness. Biochim Biophys Acta 1198: 11-26, 1994.

30. Parker BS, Argani P, Cook BP, et al: Alterations in vascular gene expression in invasive breast carcinoma. Cancer Res 64: 7857-7866, 2004.

31. Zanetta L,Corada M, Grazia Lampugnani M, et al: Downregulation of vascular endothelial-cadherin expression is associated with an increase in vascular tumor growth and hemorrhagic complications. Thromb Haemost 93: 1041-1046, 2005.

32. Vostrov AA and Quitschke WW: The zinc finger protein CTCF binds to the APBbeta domain of the amyloid beta-protein precursor promoter. Evidence for a role in transcriptional activation. J Biol Chem 272: 33353-33359, 1997.

33. Filippova GN, Fagerlie S, Klenova EM, et al: An exceptionally conserved transcriptional repressor, CTCF, employs different combinations of zinc fingers to bind diverged promoter sequences of avian and mammalian c-myc oncogenes. Mol Cell Biol 16: 2802-2813, 1996.

34. Burcin M, Arnold R, Lutz M, et al: Negative protein 1, which is required for function of the chicken lysozyme gene silencer in conjunction with hormone receptors, is identical to the multivalent zinc finger repressor CTCF. Mol Cell Biol 17: 1281-1288, 1997.

35. Filippova GN, Qi CF, Ulmer JE, et al: Tumor-associated zinc finger mutations in the CTCF transcription factor selectively alter tts DNA-binding specificity. Cancer Res 62: 48-52, 2002.

36. Kanduri C, Pant V, Loukinov D, et al: Functional association of CTCF with the insulator upstream of the $\mathrm{H} 19$ gene is parent of origin-specific and methylation-sensitive. Curr Biol 10: 853-856, 2000.

37. Rasko JE, Klenova EM, Leon J, et al: Cell growth inhibition by the multifunctional multivalent zinc-finger factor CTCF. Cancer Res 61: 6002-6007, 2001.

38. Ikeda MA, Jakoi L and Nevins JR: A unique role for the Rb protein in controlling E2F accumulation during cell growth and differentiation. Proc Natl Acad Sci USA 93: 3215-3220, 1996.

39. Yamada K, Yagihashi A, Yamada M, et al: Decreased gene expression for telomeric-repeat binding factors and TIN2 in malignant hematopoietic cells. Anticancer Res 22: 1315-1320, 2002 .

40. Karlseder J, Broccoli D, Dai Y, Hardy S and de Lange T: p53and ATM-dependent apoptosis induced by telomeres lacking TRF2. Science 283: 1321-1325, 1999.

41. Yamada M, Tsuji N, Nakamura M, et al: Down-regulation of TRF1, TRF2 and TIN2 genes is important to maintain telomeric DNA for gastric cancers. Anticancer Res 22: 3303-3307, 2002.

42. Coleman WB and Tsongalis GJ: Multiple mechanisms account for genomic instability and molecular mutation in neoplastic transformation. Clin Chem 41: 644-657, 1995.

43. Cavenee WK: Tumor progression stage: specific losses of heterozygosity. Princess Takamatsu Symp 20: 33-42, 1989. 